\title{
Morphotectonic architecture of the Transantarctic Mountains rift flank between the Royal Society Range and the Churchill Mountains based on geomorphic analysis
}

\author{
Elizabeth Demyanick ${ }^{1}$ and Terry J. Wilson ${ }^{2}$ \\ ${ }^{1}$ MDA Federal, Inc., 6011 Executive Blvd. Suite 400 Rockville MD 20852, USA (Elizabeth.Demyanick@MDAFederal.com) \\ ${ }^{2}$ School of Earth Sciences, The Ohio State University, Columbus, OH 43202-1522, USA (twilson@mps.ohio-state.edu)
}

\begin{abstract}
Extensional forces within the Antarctic Plate have produced the Transantarctic Mountains rift-flank uplift along the West Antarctic rift margin. Large-scale linear morphologic features within the mountains are controlled by bedrock structure and can be recognized and mapped from satellite imagery and digital elevation models (DEMs). This study employed the Antarctic Digital Database DEM to obtain slope steepness and aspect maps of the Transantarctic Mountains (TAM) between the Royal Society Range and the Churchill Mountains, allowing definition of the position and orientation of the morphological axis of the rift-flank. The TAM axis, interpreted as a fault-controlled escarpment formed by coast-parallel retreat, provides a marker for the orientation of the faulted boundary between the TAM and the rift system. Changes in position and orientation of the TAM axis suggests the rift flank is segmented into tectonic blocks bounded by relay ramps and transverse accommodation zones. The transverse boundaries coincide with major outlet glaciers, supporting interpretation of rift structures between them. The pronounced morphological change across Byrd Glacier points to control by structures inherited from the Ross orogen.
\end{abstract}

Citation: Demyanick, E., and T.W. Wilson (2007), Morphotectonic architecture of the Transantarctic Mountains rift flank between the Royal Society Range and the Churchill Mountains based on geomorphic analysis, in Antarctica: A Keystone in a Changing World - Online Proceedings of the 10th ISAES, edited by A.K. Cooper and C.R. Raymond et al., USGS Open-File Report 2007-1047, Short Research

Paper 096, 6 p.; doi:10.3133/of2007-1047.srp096

\section{Introduction}

The modern Transantarctic Mountains (TAM) formed as a rift-flank uplift on the margin of the West Antarctic rift system due to Mesozoic-Cenozoic extensional forces acting on the Antarctic Plate. The structural framework of the linear to curvilinear rift-flank mountain chain is interpreted as a series of asymmetric tilt blocks bounded on the West Antarctic side by a normal fault zone and subdivided by inferred transverse faults, grabens, or accommodation zones (Fitzgerald, 2002; Fitzgerald, 1992; Fitzgerald and Baldwin, 1997; Fitzgerald et al. 1986; Tessensohn and Wörner, 1991; Wilson, 1999). Normal border faulting created vertical offset along the main escarpment, forming a zone of normal faults spanning the coast, known as the TAM Front zone (Fitzgerald, 1992; Wilson, 1991, 1995). Uplift of the TAM occurred in Cretaceous and Cenozoic time, coeval with extensional episodes in the West Antarctic Rift System beneath the Ross Embayment (Fitzgerald, 2002).

The TAM rift flank is similar to other uplifted, rifted passive margins around the world (Kerr and Gilchrist, 1996), such as South Africa (Gilchrist and Summerfield, 1994). A model of a rift shoulder along a passive margin analogous to the tectonic environment of the TAM is shown in Figure 1. In his discussion of the retreat of great escarpments created during the Mesozoic and Cenozoic breakup of Gondwanaland in the Southern Hemisphere, Selby (1993) argues that the rift margins have been eroding inland in near-parallel retreat from the Late Cretaceous through Cenozoic time. The structural boundary of the rift system and the TAM rift flank presumably evolved by similar processes. Therefore, large-scale linear morphologic features within the mountains are likely controlled by rift-flank structure and can be recognized and mapped from satellite imagery and digital elevation models (DEMs). This study applied geomorphic analysis of digital topographic data to investigate the morphotectonic structure of a relatively unstudied portion of the TAM between the well-known Dry Valleys region of south Victoria Land in the north and the Churchill Mountains of the central TAM to the south (Figure 2). This sector of the TAM is of particular interest because the change in orientation of the mountain range suggests likely transverse structural boundaries. Evaluation of whether the mountain range is segmented into discrete structural blocks has been undertaken in this study in order to better understand the style of rifting that has created this long and high mountain range.

\section{Geomorphic analysis of the TAM}

Steep, rectilinear slopes and regional escarpments are commonly structurally controlled landforms and are typically associated with faulting and fracturing. Analysis of rectilinear slopes defined by escarpment patterns and lineaments identified on DEMs can thus be used to recognize regional structural trends that define the morphotectonic architecture of a faulted rift flank. Trends and offsets in structurally-controlled slopes and escarpments may also provide evidence of kinematic patterns along a rift flank.

A low-resolution (200 m) DEM was used in this study to analyze morphotectonic features along the TAM. The DEM is derived from the Antarctic Digital Database (ADD; http://www.add.scar.org/add_main.html) vector topographic data that was created from 1:250,000 scale maps with $200 \mathrm{~m}$ contour intervals, compiled under the 
auspices of the Scientific Committee on Antarctic Research (SCAR).

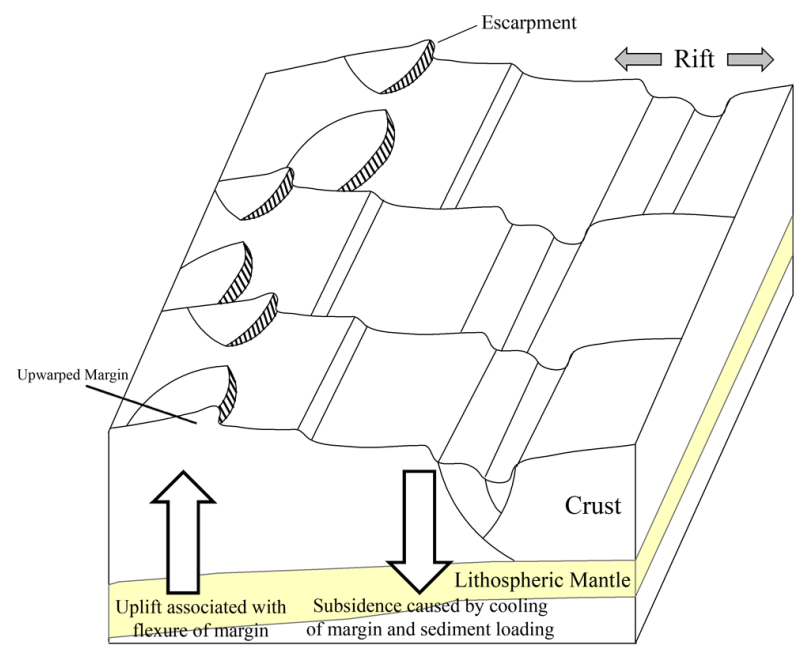

Figure 1. Schematic diagram of rift flank uplift along the margin of a rift system, similar to rifted passive margin settings (modeled after Summerfield, 1991).

\section{Hill Shade Views of the TAM}

The direction and angle of sunlight, as well as many other aspects, can be modified for enhancing structures on a DEM. Guiraud et al. (2000) stress the importance of using shaded relief maps to interpret structural lineaments by using an artificial sun angle to pick out morphological trends. Figure 2.A shows the DEM of the TAM study area with false 'sun' illumination from the southwest, putting the main east-facing TAM escarpments in shadow to highlight them effectively.

\section{Slope}

Slope is an important analytical tool in DEM analysis (Mayer, 2000). Slope steepness calculations were completed in ArcInfo 9.1 using the ADD DEM (Figure 2.C). The ArcInfo slope calculation defaults were used, including a $3 \times 3$ neighborhood size and the slope as defined by the elevation change in the horizontal and vertical directions from the center cell. In the study area, structural features remaining from the Cenozoic rifting event are expected to have greater vertical relief than those from the much older Cambrian to Ordovician Ross Orogen. Therefore, steep scarps may be related to younger normal faulting.

The slope map (Figure 2.C) documents the presence of long, linear to curvilinear slopes greater than $25^{\circ}$. The steep slopes occur parallel to the TAM coastline in the Churchill Mountains and in the Royal Society Range, and also occur along the margins of major outlet glaciers cutting across the TAM. Although lithology, lithologic heterogeneity, and cohesiveness of a rock unit are all factors in the determination of critical slope stability, Kuhni and Pfiffner (2001), for example, identified a critical mean slope angle of $25^{\circ}$ in the Swiss Alps. They postulate that the preservation of these slopes is due to the presence of permafrost, which may increase the cohesion of fractured rock masses, and the low rates of mechanical weathering caused by a lack of liquid water at high elevations. This concept is applicable to the arid polar environment that characterizes the TAM in the study region.

Slopes that are controlled primarily by rock strength are known as strength-equilibrium slopes and are found commonly in Antarctica (Selby, 1980). Because rock strength is related to structure, faulting, jointing, and bedding play a vital role in slope development. Selby (1993) argues that when rock strength is homogenous, the escarpment will experience parallel retreat and the slope will retain a constant angle through the erosion process. This is accomplished by talus accumulating at the bottom of the exposed bedrock until it gradually in-fills the concave slope, thereby maintaining the talus angle. These are known as Richter slopes, and are commonly found in Antarctica (Selby, 1993). This slow backward movement of the rock wall and clearly defined slope allows for recognition of escarpment retreat even after erosive processes have operated for a long time. The major coastparallel slopes defined by the TAM slope map (Figure 2.C) are interpreted as fault-controlled escarpments that have retreated westward from the coastal structural boundary zone.

\section{Aspect}

ArcGIS was used to define slope aspect, which classifies slopes based on their geographic 'facing direction'. In this study, aspect has been used in order to display east- and west- facing slopes (Figure 3.A) relative to a vertical grid direction. Slopes less than $2^{\circ}$ were masked out in order to reduce noise caused by small undulations in the ice sheet. A clear regional change from eastward slopes, facing the coastline, to westward slopes facing the polar plateau margin, occurs along this sector of the TAM. The east-west slope divide tracks the topographic axis of the TAM (yellow lines, Figure 3.B). The aspects were chosen because they are perpendicular to the general trend of the mountain range in this sector of the TAM. In general, the TAM topographic axis parallels the trend of the coastline, but the aspect divide curves in proximity to the major outlet glaciers such as the Byrd Glacier.

\section{Structural model based on TAM morphology}

The crustal geometry of the TAM is relatively well known in southern Victoria Land, where the rifted margin occurs on the seaward side of the major drainage divide, along the coastal zone of the mountain range (Fitzgerald et al., 1986). The area to the east of the drainage divide is interpreted to be part of the TAM Front structural boundary. Previous workers have shown that brittle faulting is localized along the coastal TAM Front (Fitzgerald, 1992; Wilson, 1992, 1995) and have 




Figure 2. A. $225^{\circ}$ hillshade of ADD DEM in study area. Yellow arrow is illumination direction; white grid is latitude and longitude. RSR is Royal Society Range; WR is Worcester Range; southern Victoria Land includes the section of the TAM extending from the Dry Valleys to the Byrd Glacier. B. ADD DEM color ramp of the study area; the TAM Front Zone is inferred to follow the coastline, separating the uplifted rift-flank mountains from the rift system beneath the Ross Sea and Ross Ice Shelf. C. Slope map of study area. Classification values were set using the slope histogram.

interpreted the main morphological escarpment of the TAM as a fault-line escarpment related to the coastal fault zone (Kerr et al., 2000). The escarpment axis, therefore, provides a marker for the rift border fault system and can be used to map the fault-controlled escarpment.

The slope aspect map has been used to map the pattern of the TAM morphotectonic axis (Figure 3.B), defined as the major divide on the east-west facing aspect map. The position and orientation of the morphotectonic axis varies along the strike of the TAM, providing evidence of TAM segmentation into structural blocks (Figure 3.C). Prominent changes in the orientation of the TAM axis occur both across Byrd Glacier, between the Churchill Mountains and the Britannia Range, and across the
Darwin Glacier, between the Britannia Range and the Cook Mountains. If the TAM axis escarpment is structurally controlled, then this suggests segmentation across Byrd Glacier, as well as between the Britannia Range and Cook Mountains. From the Cook Mountains northward, there is a systematic eastward shift in the position of the TAM axis as defined on the slope aspect map (Figure 3.B). These shifts are coincident with the main outlet glaciers.

\section{Discussion}

Overlap in the position of rift border faults and trend changes along rift axes are associated with transverse structures known as accommodation zones (e.g., Morley 


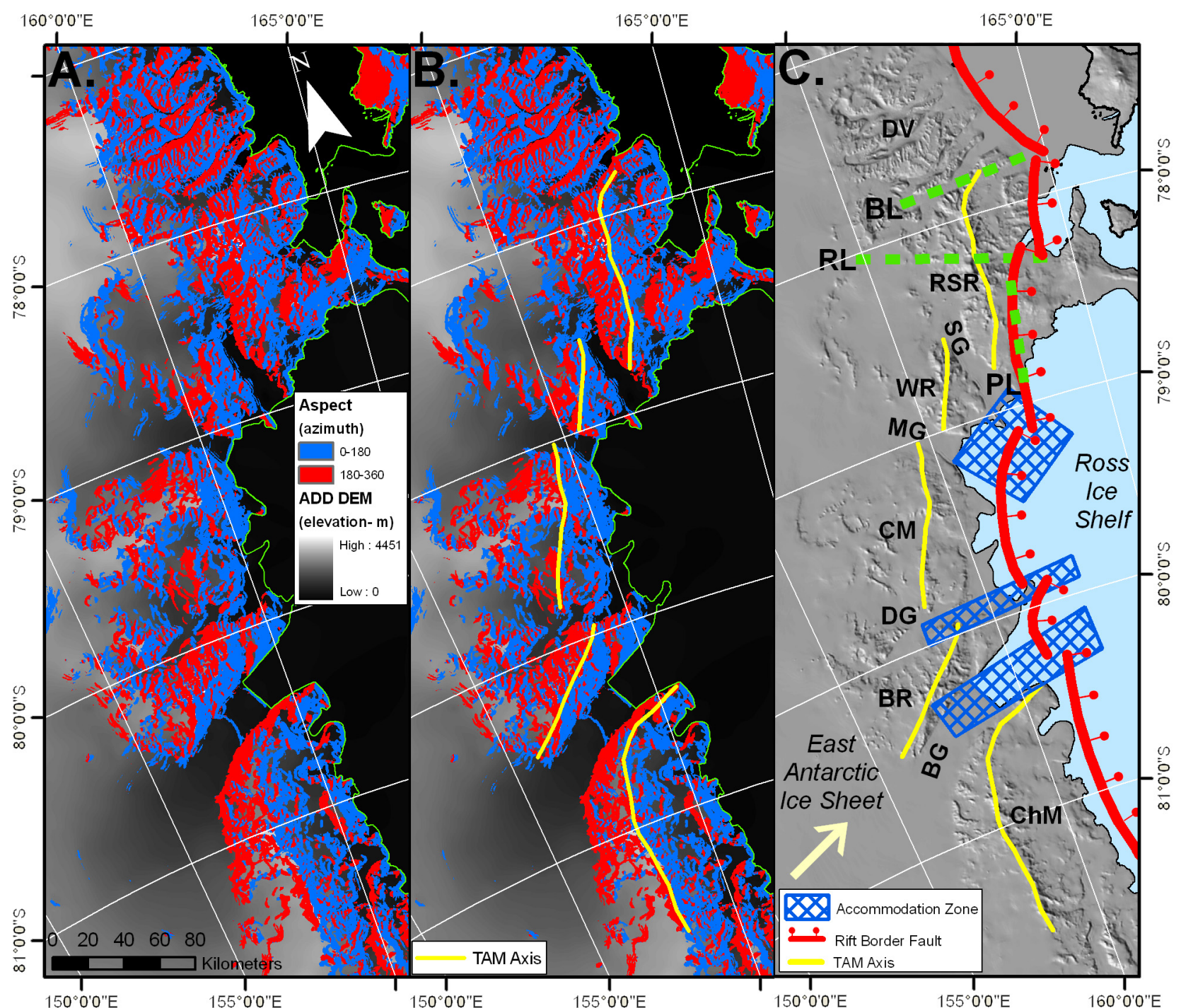

Figure 3 A. East-west aspect image where east is defined as hill slopes facing $0^{\circ}-180^{\circ}$ and west is defined as hill slopes facing $180^{\circ}-360^{\circ}$. These measurements were calculated in ArcGIS using a grid that is vertical and parallel to the figure boundaries, not parallel to the longitude (show by the white grid on the figures). B. Aspect map of east- and westfacing slopes with the major divides mapped as the TAM morphologic axis. C. Hillshade at $225^{\circ}$ overlain by a structural model for the TAM between the Royal Society Range and the Churchill Mountains. The position of the main border faults between the rift flank and the offshore rift system are inferred to lie outboard of the easternmost bedrock in the TAM, and the orientation is inferred from the dominant trend of the TAM escarpment in each TAM block. DV is Dry Valleys; RSR is Royal Society Range; SG is Skelton Glacier; WR is Worcester Range; MG is Mulock Glacier; CM is Cook Mountains; DG is Darwin Glacier; BR is Britannia Range; BG is Byrd Glacier; ChM is Churchill Mountains; BL is Blue Lineament; RL is Radian Lineament; PL is Pyramid Lineament. Wilson (1999) previously examined these three lineaments.

et al., 1990). Where rift faults have the same sense of displacement but overlap each other, the change in elevation between the hanging wall and footwall of adjacent segments is accommodated by a 'relay ramp' (Figure 4). Because the TAM border faults have the same down-to-the-rift displacement in each segment, overlapping fault-controlled escarpments along the TAM most likely are the signature of such relay ramp structures connecting offset segments of the TAM rift flank.

Accommodation zones have been defined where the
TAM morphotectonic axis shifts position laterally and/or changes trend. The TAM Front border fault system is inferred to follow the main trend of the morphotectonic axis (inferred fault-line escarpment) and placed outboard of all non-volcanic bedrock along the coast of the TAM.

Previous work by Fitzgerald (2002) has summarized the TAM in this region to be segregated into three discrete structural blocks. These include the Royal Society Range Block from Ferrar Glacier in the Dry Valleys to the Radian Lineament, the Cook Block from the Radian 
Lineament south to Byrd Glacier, and Churchill Block from Byrd Glacier south to Nimrod Glacier, which is south of the selected study area. Wilson (1999) inferred

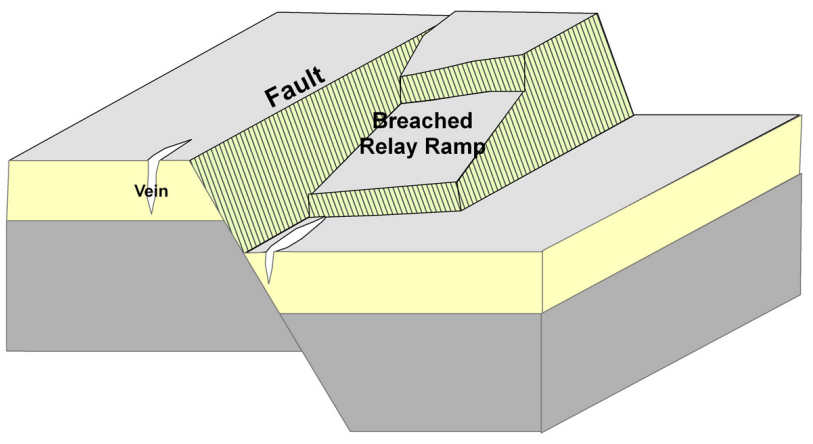

Figure 4. Block model of normal faults and relay ramps (modified from Peacock, 2002).

that two discrete structural blocks can be defined in the area from the Blue Lineament south to Mulock Glacier, separated by the Radian Lineament.

This study defines a similar Royal Society Range Block and Churchill Block to those presented by Fitzgerald (2002). The Cook Block, as defined by Fitzgerald (2002) has been found to be segmented in two places: at Mulock Glacier and Darwin Glacier. Going south from Skelton Glacier to Mulock Glacier, there appears to be a westward step in the axis of the TAM. This pattern suggests an accommodation zone and possible relay-ramp structure across the Worcester Range. The offset axis of the Britannia Range as compared to the trends of the the Cook Mountains to the north and Churchill Mountains to the south suggests an accommodation zone in the vicinity of the Darwin Glacier.

The discrepancy in lithology on either side of Byrd Glacer has long been recognized (Grindley and Laird, 1969) and has become known as the Byrd Glacier 'discontinuity,' strongly suggesting an underlying structure to cause this relationship. This structure has been linked with the segmentation of the West Antarctic rift system and possible termination or offset of rift basins beneath the Ross Sea and Ross Ice Shelf (e.g. Davey, 1981; Cooper et al., 1991; Tessensohn, 1994; Mazzarini et al., 1997). Evidence examined by Stump et al. (2006) suggests that the discontinuity evolved into an oblique subduction boundary during the Ross Orogeny, thus suggesting Ross Orogen control over the accommodation zone.

\section{Summary}

This morphotectonic interpretation of the TAM provides new evidence of segmentation by structures associated with major outlet glaciers, as suggested by previous workers, and provides a new model for the structural architecture of the Royal Society Range to Churchill Mountains sector of the TAM rift flank. The orientation of border faults approximately follows the rift- margin coastline, paralleling the fault-line escarpment marked by the TAM morphologic axis, defined by the prominent 'divide' between east- and west-facing slopes. Relay-ramp type accommodation zones were identified based on the orientation and position of the TAM morphological axis. A relay-ramp accommodation zone is interpreted at Mulock Glacier, between the Worcester Range and the Cook Mountains. Across Darwin Glacier and Byrd Glacier, changes in the orientation and position of the TAM escarpment suggest additional rift-related accommodation zones. The Byrd Glacier structure is most likely inherited from the Ross orogen 'discontinuity.'

Acknowledgements. This research was partially supported by The National Science Foundation award ANT-0125624 to T.J. Wilson. Special thanks to the referees, Dr. Beata Csatho and Dr. Lindsay Schoenbohm, and the co-editor, Paul Fitzgerald.

\section{References}

Cooper, A. K., J. A. Crame, editor, F. J. Davey, K. Hinz, J. W. Thomson, editor (1991), Crustal extension and origin of sedimentary basins beneath the Ross Sea and Ross Ice Shelf, Antarctica, International Symposium on Antarctic Earth Sciences, 5. Cambridge New York : Cambridge University Press.

Davey, F. J. (1981), Geophysical studies in the Ross Sea region, Journal of the Royal Society of New Zealand, 11, 465-479.

Fitzgerald, P. G., M. Sandiford, P. J. Barrett, A. J. W. Gleadow (1986), Asymmetric extension associated with uplift and subsidence of the Transantarctic Mountains and Ross embayment, Earth and Planetary Science Letters, 81, 67-78.

Fitzgerald, P. G. (1992), The Transantarctic Mountains of southern Victoria Land: The application of apatite fission track analysis to a rift shoulder uplift, Tectonics, 11, 634-662.

Fitzgerald, P. (2002), Tectonics and landscape evolution of the Antarctic plate since the breakup of Gondwana, with an emphasis on the West Antarctic Rift System and the Transantarctic Mountains, Antarctica at the close of a millennium, Royal Society of Museum Bulletin, 35, 453-469.

Fitzgerald, P. G., S. Baldwin (1997), Detachment fault model for the evolution of the Ross Embayment, In: Ricci, C. A. (Ed.), The Antarctic Region: Geological Evolution and Processes, Terra Antarctica Publication, Siena, 555-564.

Gilchrist, A. R., M. A. Summerfield (1994), Tectonic models of passive margin evolution and their implications for theories of long-term landscape development, Process models and theoretical geomorphology, Chichester: John Wiley and Sons.

Grindley, G. W., M. G. Laird (1969), Geology of the Shackleton Coast, Antarctic Map Folio Series, Folio 12, XIV. New York: American Geographical Society.

Guiraud, R., J-C. Doumnang Mbaigane, S. Carretier, S. Dominguez (2000), Evidence for a $6000 \mathrm{~km}$ length NW-SE-striking lineament in northern Africa: the Tibesti Lineament. J. Geological Society, London, 20, 897-900.

Hughes, T. (1977), West Antarctic ice streams, Reviews of Geophysics and Space Physics, 15, 1, 1-46.

Kerr, A., A. Gilchrist (1996), Glaciation, erosion and the evolution of the Transantarctic Mountains, Antarctica, Annals of Glaciology, 23, 303-308.

Kerr, A., D. E. Sugden, M. A. Summerfield (2000), Linking tectonics and landscape development in a passive margin setting: the Transantarctic Mountains, In: M. A. Summerfield (Ed.), Geomorphology and Global Tectonics, New York: John Wiley and Sons Ltd.

Kuhni, A., O. A. Pfiffner (2001), The relief of the Swiss Alps and adjacent areas and its relation to lithology and structure: topographic analysis from a 250-m DEM, Geomorphology, 41, 285-307.

Mayer, L (2000), Application of digital elevation models to macroscale tectonic geomorphology, In: M. A. Summerfield (Ed.), 
Geomorphology and Global Tectonics, New York: John Wiley and Sons Ltd., 15-27.

Mazzarini, F., B. D. Vedova, F. Salvini (1997), Crustal Segmentation of the Transantarctic Mountains Rift Shoulder along the David Glacier Lineament, Victoria Land (Antarctica.), The Antarctic Region: Geological Evolution and Processes, 565-569.

Morley, C. K., S. G. Munn, R. A. Nelson, T. L. Patton (1990), Transfer zones in the East African Rift system and their relevance to hydrocarbon exploration in rifts, AAPG Bulletin, 74, 8, 1234-1253.

Peacock, D. C. P. (2002), Propagation, interaction and linkage in normal fault systems, Earth-Science Reviews, 58, 1-2, 121-142.

Selby, M. J. (1980), A rock mass strength classification for geomorphic purposes: with tests from Antarctica and New Zealand, Zeitschrift fur Geomorphogic, 24, 1, 31-51.

Selby, M. J. (1993), Hillslope Materials and Processes, Oxford University Press: Oxford.

Stump, E., B. Gootee, F. Talarico (2006), Tectonic Model for Development of the Byrd Glacier Discontinuity and Surrounding Regions of the Transantarctic Mountains during the NeoproterozoicEarly Paleozoic, In: K. Futterer, D. Damaske, G. Kleinschmidt, H. Miller, F. Tessensohn (Eds), Antarctica: Contributions to Global Earth Sciences, New York: Springer, 181-190.

Summerfield, M. A. (1991), Global Geomorphology, Prentice-Hall: New York.

Tessensohn, T. (1994), LIRA; Lithospheric Investigations in the Ross Sea area, Terra Antartica, 1, 1, 226-228.

Tessensohn, F., G. Worner (1991), The Ross Sea rift system, Antarctica: structure, evolution and analogues, In: M. R. A. Thomson, J. A. Crame, J. W. Thomson (Eds.), Geological Evolution of Antarctica, Cambridge University Press, New York, 273-277.

Wilson, T.J. (1992) Mesozoic and Cenozoic kinematic evolution of the Transantarctic Mountains, In: Y. Yoshida, K. Kaminuma, K. Shiraishi (Eds.), Recent Progress in Antarctic Earth Science, Terra Scientific Publishing: Tokyo, 303-314.

Wilson, T.J. (1995), Cenozoic transtension along the Transantarctic Mountains- West Antarctic rift boundary, southern Victoria Land, Antarctica, Tectonics, 14, 531-545.

Wilson, T.J. (1999), Cenozoic structural segmentation of the Transantarctic Mountains rift flank in southern Victoria Land, Global and Planetary Change, 23, 105-127. 